\title{
Language Preferences in Romanian Communication Sciences Journals: A Web-Based Analysis
}

\author{
Mariana Cernicova-Buca
}

check for updates

Citation: Cernicova-Buca, M. Language Preferences in Romanian Communication Sciences Journals: A Web-Based Analysis. Publications 2021, 9, 11. https://doi.org/10.3390/ publications 9010011

Received: 30 December 2020

Accepted: 9 March 2021

Published: 11 March 2021

Publisher's Note: MDPI stays neutral with regard to jurisdictional claims in published maps and institutional affiliations.

Copyright: (c) 2021 by the author Licensee MDPI, Basel, Switzerland. This article is an open access article distributed under the terms and conditions of the Creative Commons Attribution (CC BY) license (https:// creativecommons.org/licenses/by/ $4.0 /)$.
Department of Communication and Foreign Languages, Politehnica University Timisoara, 300006 Timisoara, Romania; mariana.cernicova@upt.ro

Abstract: In modern times, English has become the lingua franca of science, dominating journal publishing ecologies. Multilingual journals keep up the flag, many researchers arguing that, especially in the case of social sciences and humanities, diversity of languages is an asset. In Romania, in the absence of national databases or repositories, the first task to understand linguistic preferences for scientific communication is to map the ground. The study extracted information on Romanian communication sciences journals from four major databases. Out of the 22 identified journals, only eight are dedicated solely to communication sciences, grouped in two poles of communication sciences schools, where doctoral studies in the field have been established. While English dominates the publication world, multilinguistic journals also appear, prevailing in traditional multicultural regions such as Transylvania-Banat. The future of multilingual journals depends on, among other factors, the capacity of the European Union to promote linguistic diversity for scientific purposes. Meanwhile, Romanian journals in communication sciences work towards increasing their impact. Research findings have practical and policy implications, the core idea being that Romanian editors need to strive for better standards in publication and showcase the journals better on the journal's webpage.

Keywords: language preference; academic journal; multilingualism; national language; lingua franca; communication sciences

\section{Introduction}

Sharing scientific knowledge through publication is a sine qua non condition of science development, part of the DNA of scientists all over the world. The language of science, however, changed in time. Latin gave way to modern languages reluctantly. In the 17 th and 18th century, for instance, mathematicians (like Leonhard Euler) and physicists (like Isaac Newton) wrote scientific papers in Latin, even if for other purposes they used modern languages. The Proceedings of St. Petersburg Academy, founded in the 1740s, had two official languages: Latin for mathematics and French for all other sciences. In 19th century Europe, German consolidated its status as a language of philosophy, French as a language of diplomacy and humanities, and so forth. As David Banks points out, in 1880 English accounted for less than $40 \%$ of scientific publications and by 1910 it had fallen to $30 \%$ [1]. From then on, the share of English publications in the scientific world rose at an uneven pace: by 1930 it had risen to about 50\%, then seemed to maintain a plateau, after which it gained speed up to the point that in 1997 John Swales named it a "Tyrannosaurus rex", behaving like "a powerful carnivore gobbling up the other denizens of the academic linguistic grazing grounds" [2] (374). The term was soon picked up and debated in research on the use of languages for scientific purposes [3,4], English becoming the "lingua franca" of modern times [1,5,6]. In the early 20th century, from 1910 to the mid-1920s, German had a greater share of scientific publications than English. In 1920, German accounted for over $40 \%$ of publications, English a little over 30\%, and French just over 10\% [1]. In the second half of the 20th century, however, English surpassed all other languages and, even though it is not the most widely spoken language in the world, started dominating the language of science [7]. Today most scientists feel pressure to publish their papers in 
English-language journals, to attract the citations and impact that their mother tongue cannot $[7,8]$. The former "publish or perish" belief of scientists turned into "publish in English or perish" model, as proven by the fact that in natural and medical sciences (NMS), for instance, more than 98\% of peer-reviewed documents in the NMS published in 2014 and indexed in the Web of Science were in English [8]. Rogerio Meneghini and Abel L. Packer, in their opinion piece "Is there science beyond English?" [9] called for initiatives to salvage the multilingual world and, with it, to preserve diversity and tear down the barriers in scientific communication. They pointed out that it would take an international effort on the part of editors, index providers, and authors, as well as support from national research agencies interested in developing native scientific languages and increasing both the national and the international visibility of national research [9]. A similar view is shared by Françoise Salager-Meyer [10], who highlighted the fact that "national languages are playing an increasingly important role in many countries where academic reward systems take into consideration publications in domestic journals. Indeed, multilingual scholars across disciplines often resort to both English and national languages to facilitate national scholarly exchange of ideas and new knowledge dissemination" [10,11].

Indeed, in non-English speaking countries, the choice of language for scientific communication was (and still is) a painstaking decision, with multiple implications of political, symbolic, and scientific consequences. Cultural traditions, (old) alliances, and political choices play their role in the ultimate choices. For a brief period, for instance, in the second half of the 20th century in Central and Eastern Europe, Russian was the language of science, while after the disappearance of the USSR in 1991, this language lost ground even in Russia [12]. Writing in the national language was, in Central and Eastern Europe, a matter of asserting the national identity, of developing the language and terminology in the native tongue, of overcoming a situation in which the local language was only for private use, while the language of public life was French, German, Hungarian, or Russian-depending on the specific geopolitical and temporal context. In the second half of the 20th century, the prestige of the national language was no longer challenged, but the 21st century and the acceleration of globalization forces brought along a reopening of the debate on the choice of publication languages for scientific output. To take only the Romanian example, the national standard for promotion in academic careers is tied to publishing in foreign languages (English, French, German, Italian, Spanish), these results carrying a heavier load than the ones published in Romanian [13].

In 2007, the European Union emphasized its commitment to fostering diversity in language use, appointing its first Commissioner for Multilingualism in the European Commission, Mr. Leonard Orban (from Romania), with a portfolio dedicated exclusively to promoting foreign language learning and use throughout the member states of the EU [14]. A decade later, the progress-in promoting multilingualism for scientific purposes-is not impressive. As Gunnar Sivertsen pointed out, language is invisible in most documents related to this topic, including the "Work Programme 2018-2020 for Science with and for Society" [15]. Appeals to support multilingual scientists increase in the scientific community $[11,16,17]$, some with concrete proposals, but the result is invisible in most documents. At least the first two decades of the 21st century seem to consecrate English as the lingua franca of science, across disciplines $[1,5,18,19]$. And while scientific writing is remarkably diverse and language preferences are not only domain-bound, but also influenced by national policies, social sciences and humanities (SSH) excel in the variety of publication patterns with languages, types, and coverage in databases, this reality being associated with problems in research evaluation [15]. Social sciences and humanities are typically associated with influencing and improving culture and society, by contributing to the identity-building of a given society, which motivates an inclination towards scholarly publishing at least partly in native languages. Also, "the social sciences, humanities, and law (SSH) are known to have more heterogeneous publication patterns than the sciences, medicine, and technology (STM)", as shown by a report on science, technology, and innovation indicators [20]. The report also points to the fact that while there is a 
gradual and stable increase in English language publishing in the SSH, "there are also large differences between the disciplines, indicating that the bilingual situation will prevail in the SSH due to the societal obligations and wider audiences" [20].

To acknowledge this and maintain a level of certified quality, a special repository was created at the end of the 20th century, the Central and Eastern European Online Library (CEEOL), which collaborates with over 1200 publishers and numerous nonaffiliated researchers, in more than 50 languages. In its own words, the Germany-based CEEOL [21] "took responsibility and advocacy for academic publishing in Humanities and Social Sciences in the respective native languages" from Europe and beyond. A similar philosophy animates the Poland-based Index Copernicus, an online database that aims at separating quality scientific journals from the predatory enterprises that abound in the digital world [22]. However, in academia, two databases occupy a leading position when evaluating the impact of research: Scopus and Clarivate Analytics/ISI. They are the most widely used tools for journal evaluation, assessment, and ranking; studies show that articles indexed in these databases also attract the largest number of citations, a core sign for the impact of published research output. For these two databases, English is, by far, the leading language, despite the possibility of accepting other languages as well [23].

In the context of these linguistic realities and debates, this study aims at identifying the language preference in communication sciences in Romania, a scientific branch new to the field of social sciences [24] and new as an area of specialization, practice, and research in this country, with a history of less than three decades (Palea [25]). We will treat communication sciences as a special case within the larger SSH group, since previous studies show that there are differences between disciplines along several indicators, linguistic preferences included [20].

The research needs to start by mapping the territory, since no relevant databases have been created on the national level.

In 2005, around 600 scientific journals applied for evaluation to the National Council of Scientific Research [26]. In 2008, the number raised to over 900 scientific journals that applied for recognition and classification with the National Council of Scientific Research [27]. Evidence for the existence of these journals is difficult to trace. Journals have changed names, affiliations, periodicity, languages, scope, and procedures. A European attempt in 2017 to systematize the field in social sciences and humanities underlined the fact that Romania lacks national databases or repositories that would help identify SSH journals [28]. Also, a COST project (EU funded through the European Cooperation in Science and Technology programme) on initially eight non-English speaking countries dealing with publication patterns in SSH placed Romania under the "no data" rubric in 2018, the project continuing without Romania present, for the remaining seven countries [18]. Academics commenting on Romanian journals are dissatisfied with the quality of these outputs, going so far as to state that a significant portion of the titles called scientific do not actually serve science but are merely scientific popularization journals [29]. Other voices are critical towards the prevalence given to international languages over Romanian [30], deploring the fact that the national language no longer serves the larger public. Our study does not analyze Romanian language-only journals in the selected field of science, because they are not included in any relevant database or repertoire, thus lacking the chance to attract valuable manuscripts. On the other hand, the number of Romanian scholarly journals using English or multilingual media, indexed in international scientific databases, increased significantly in recent years, partly due to the upgrading standards set by the Romanian institutions in charge of the various aspects of academic life (financing, accreditation, career advancement of academics, etc.), partly due to lessons learned from experience in publishing and adding value to the research output [31]. The appraisal of the scientific landscape should, however, start with a clearer image of the territory. This motivated us to set forth the following research objectives:

RO1: To map the field of communication sciences journals in Romania. 
RO2: To identify the language preferences displayed by Romanian communication sciences journals.

\section{Materials and Methods}

This paper focuses only on Romanian journals that are indexed in the Web of Science (WoS), Scopus, ERIH+, and/or CEEOL. The data we used were gathered in June-August 2020. The list of journals was extracted from the websites of these databases and only included journals active in 2020 that are Romania-based. We chose to include all journals that contained a reference to communication studies among the scientific domain specified in the journal description, to get the largest possible picture. Only two Romanian communication science journals are indexed in the Web of Science and they are still in the "emerging" phase of recognition. One of the two journals is also indexed in Scopus. ERIH+ and CEEOL offer a larger image of the field, but additional steps in refining information proved to be necessary, to extract communication science journals out of the several hundreds of listed journals. This study focuses on obtaining information regarding aspects of linguistic preferences in communication sciences publishing (use of language on the webpage of the journal, templates offered, languages of publication for articles, language publication for abstracts, other language-related aspects), as well as general aspects regarding scientific publishing (number of issues per year, indexation preferences). The data regarding these aspects were gathered from the mentioned databases and double-checked on the journals' websites. One journal was added to the list, namely the Romanian Journal of Journalism and Communication [Revista Română de Jurnalism și Comunicare], which is indexed in other databases considered prestigious in the Romanian journal classification system and is coedited by the Romanian Association of Teachers in Journalism and Communication. In cases where contradictions in information appeared, preference was given to information extracted from the journal website, which is curated by the editorial board. We designed a data collection form to systematically follow through the desired parameters and were able to identify 22 indexed journals that explicitly mention communication studies among their scientific area of interest and/or expertise (Appendix A). In the next step, we tried to identify a pattern in linguistic choices (English only vs. bi- or multilingual publishing) according to regional dispersion of the parenting research unit (university/department/faculty/research center). Information collected from the journal's homepage was cross-referenced with a verification of the last issue of the journal and with at least two other issues picked randomly on the website, to check the consistency of choices announced in the editorial matter and the description of the journal provided for the databases.

From a historical point of view, Romanian regions had different linguistic traditions: the national capital, the region around it, and Moldova had a strong French affiliation, while in Transylvania-Banat, a multicultural and multilingual type of communication was in use. It was interesting to test whether the tradition survived in the 21st century, with English as a first medium of choice for scientific publishing. Finally, we refined the data and focused on the journals that are committed to further knowledge in communication sciences only, since the initial pool showed that many SSH journals try to embrace a "catch-all" model and use the term in a rather loose meaning, not necessarily covering content pertaining to communication sciences. The confusions are easy to understand. Although communication sciences have been taught in Romania since 1991 [25], it was only in 2004 that they were included as a distinctive branch of social sciences in the Romanian institutions dealing with the evaluation of research output. Also, since in the 1990s some faculties of letters started communication sciences/journalism programs, communication sciences are often associated with philology, education sciences, cultural studies, arts, and so forth [32]. 


\section{Results and Discussion}

\subsection{Overview of Scientific Journal Publishing in Contemporary Romania}

Academic journals traditionally embody four functions: registration (third-party establishment by date-stamping of the author's precedence and ownership of an idea), dissemination (communicating research findings to intended audiences), certification (ensuring quality control through peer review), and archival record (preserving a fixed version of the paper for future reference and citation) [33]. As a distinctive feature, it is expected that journal articles bring new / fresh results to audiences, even disseminate work in progress, while books and monographs have longer production cycles and a broader scope. The obligation, on the part of academics, to have published at least one scientific article per year as proof of scientific research and that their teaching is grounded in original research grew into a written provision that the teaching staff in higher education need to present in a scientific event and/or publish such an outcome of an academic year's work [34]. The frenzied appearance of journals in the early 1990s was the institutional response to the above-mentioned requirement. In time, the Romanian academic world matured and had to face quality measures, such as reinforcing the tradition of peer review and introducing indexing/abstracting services, to be capable of attracting quality content and international scholars. We selected for the study three of the databases that are evidenced distinctively in national research reports across disciplines, WoS, Scopus, and $\mathrm{ERIH}+$, and a fourth venue, the repository CEEOL, specific for SSH and for giving credit to scientific progress in a multicultural and multilinguistic environment.

To be taken into consideration as counting towards academic career advancement, SSH journals selected by Romanian academics for publishing currently need to be indexed/abstracted in at least three relevant databases (the list is provided). Thus, in some cases indexations overlap, but this ensures the journal a stronger position in the scientific landscape [26]. The first two databases gave, for communication studies, modest results: two journals are indexed in WoS (ESCI) and one of the two is also covered by SCOPUS. At the other end, CEEOL gave several hundred results, which needed manual extraction of information, since communication sciences are incorporated into the larger category of social sciences. Between them, CEEOL and ERIH+ refined the results down to 22 titles (Appendix A), ERIH+ having the advantage that it not only defines communication sciences (and media) as a separate category, but explicitly provides information about the language(s) of publication and the link to the publication itself. Table 1 below presents the scientific focus of the journals declared on the website and/or description provided for indexing in the mentioned databases, in alphabetical order. We use the term "scientific focus" to indicate the fields of study that the editors describe as specific for the given journal.

Table 1. List of Romanian communication sciences journals by city and scientific focus.

\begin{tabular}{llll}
\hline \multicolumn{1}{c}{ Journal } & City & \multicolumn{1}{c}{ Scientific Focus } \\
\hline 1. Acta Universitatis Sapientiae, Communicatio & Cluj & $\begin{array}{l}\text { theoretical and empirical research in } \\
\text { communication studies, with a focus on } \\
\text { information society issues }\end{array}$ \\
\hline $\begin{array}{l}\text { 2. Acta Universitatis Sapientiae, Film and } \\
\text { Media Studies }\end{array}$ & Cluj & film and media \\
\hline $\begin{array}{l}\text { Annals of the University of Craiova for } \\
\text { and Management }\end{array}$ & Craiova & journalism, communication, and management \\
\hline $\begin{array}{l}\text { Buletinul Institutului Politehnic din Iași } \\
\text { sectia Stiinte Socio-Umane }\end{array}$ & Iasi & $\begin{array}{l}\text { language and literature (applied linguistics, } \\
\text { literary studies, theatrical and cinematic discourse, } \\
\text { foreign language learning/teaching, translation } \\
\text { studies); social sciences (education, psychology, } \\
\text { philosophy, communication studies) }\end{array}$ \\
\hline
\end{tabular}


Table 1. Cont.

\begin{tabular}{|c|c|c|c|}
\hline & Journal & City & Scientific Focus \\
\hline 5. & $\begin{array}{l}\text { Buletinul Științific al Universității Tehnice de } \\
\text { Construcții București Seria: Limbi Străine } \\
\text { și Comunicare }\end{array}$ & Bucharest & humanistic debates (SSH) \\
\hline 6. & Communication Interculturelle et Littérature & Galati & $\mathrm{SSH}$ \\
\hline 7. & Cultural Intertexts & Galati & $\mathrm{SSH}$ \\
\hline 8. & Ekphrasis. Images, Cinema, Theory, Media & Cluj & cinema, media, and cultural studies \\
\hline 9. & HyperCultura & Bucharest & $\begin{array}{l}\text { literature (print and hypertext), media studies } \\
\text { (radio, television), film studies, visual and } \\
\text { performative arts, teaching (language, } \\
\text { literature, rhetoric) }\end{array}$ \\
\hline 10. & $\begin{array}{l}\text { Information and Communication } \\
\text { Sciences Research }\end{array}$ & Bucharest & information and communication sciences \\
\hline 11. & $\begin{array}{l}\text { Journal of Communication and } \\
\text { Behavioural Sciences }\end{array}$ & Bucharest & $\begin{array}{l}\text { history of communication and behavioral sciences, } \\
\text { the professional practice of communication, } \\
\text { psychology, cognitive science, and anthropology, } \\
\text { communication and behavioral sciences training } \\
\text { and education, and communication and behavioral } \\
\text { sciences practice and new technology }\end{array}$ \\
\hline 12. & Journal of Media Research & Cluj & media and communication \\
\hline 13. & ME.DOK Média-Történet-Kommunikáció & Cluj & $\begin{array}{l}\text { history of journalism, contemporary media } \\
\text { analyses, studies on the general problem of } \\
\text { communication }\end{array}$ \\
\hline 14. & $\begin{array}{l}\text { Professional Communication and } \\
\text { Translation Studies }\end{array}$ & Timisoara & $\begin{array}{l}\text { communication }+ \text { translation studies }+ \text { didactics of } \\
\text { foreign languages }\end{array}$ \\
\hline 15. & Revista Română de Jurnalism și Comunicare & Bucharest & communication studies \\
\hline 16. & $\begin{array}{l}\text { Romanian Journal of Communication and } \\
\text { Public Relations }\end{array}$ & Bucharest & communication studies \\
\hline 17. & Saeculum ULBS & Sibiu & social sciences and humanities \\
\hline 18. & $\begin{array}{l}\text { Social Sciences and Education } \\
\text { Research Review }\end{array}$ & Craiova & universe of social sciences \\
\hline 19. & $\begin{array}{l}\text { Studia Universitatis } \\
\text { Babes-Bolyai-Ephemerides }\end{array}$ & Cluj & communication studies \\
\hline 20. & $\begin{array}{l}\text { Studies in Visual Arts and } \\
\text { Communication-An International Journal }\end{array}$ & Iasi & arts and communication \\
\hline 21. & Styles of Communication & Bucharest & communication studies \\
\hline 22. & Technium Social Sciences Journal & Constanta & $\begin{array}{l}\text { humanities + social sciences (among which is } \\
\text { communication studies) }\end{array}$ \\
\hline
\end{tabular}

The results were further analyzed from the point of view of linguistic practices, taking into consideration the following parameters: the language of the website (instructions for authors), the official language of publication, the language of the abstract, additional languages for abstracts (if required), as presented in Table 2 below. For abstracts written in the same language as the article, the abbreviation ART LG is used. 
Table 2. Language preferences displayed by the journals.

\begin{tabular}{|c|c|c|c|c|c|c|c|c|c|c|c|c|}
\hline Nr. Journal & & Web & ges 1 & & & & $\overline{\mathbf{P u b}}$ & tion & & & Abstract LG & + Abstract lg \\
\hline 1. & EN & & & & EN & & & & & & EN & \\
\hline 2. & EN & & & & EN & & & & & & EN & \\
\hline 3. & EN & & & & EN & & & & & & EN & \\
\hline 4. & EN & & & & EN & & FR & & & & ART LG & $+\mathrm{RO}$ \\
\hline 5. & EN & & & & EN & & FR & GE & & ESP & ART LG & \\
\hline 6. & EN & RO & $\overline{F R}$ & & EN & RO & FR & & & & ART LG & + EN / FR for RO \\
\hline 7. & EN & & & & EN & & & & & & EN & \\
\hline 8. & EN & & FR & & EN & & & & & & ART LG & \\
\hline 9. & EN & & & & EN & & & & & & EN & \\
\hline 10. & EN & RO & FR & & EN & & & & & & & $\mathrm{EN}+\mathrm{RO}+\mathrm{FR}$ \\
\hline 11. & EN & & & & EN & & & & & & EN & \\
\hline 12. & EN & & & & EN & & & & & & ART LG & $+\mathrm{EN}$ \\
\hline 13. & EN & & & $\mathrm{HU}$ & EN & RO & & & HU & & $\mathrm{EN}+\mathrm{RO}$ & \\
\hline 14. & EN & & & & EN & & FR & GE & & & ART LG & $+\mathrm{EN}$ \\
\hline 15. & EN & RO & & & EN & & FR & GE & & ESP & ART LG & $+\mathrm{EN}$ \\
\hline 16. & EN & & & & EN & & & & & & EN & \\
\hline 17. & EN & RO & & & EN & RO & FR & GE & & & EN & \\
\hline 18. & EN & & & & EN & & & & & & EN & \\
\hline 19. & EN & RO & & & EN & & & & & & EN & \\
\hline 20. & EN & & & & EN & & FR & & & ESP & ART LG & $+\mathrm{EN}$ \\
\hline 21. & EN & & & & EN & & & & & & EN & \\
\hline 22. & EN & & & & EN & & & & & & EN & \\
\hline
\end{tabular}

The order of the journals is the same as in Table 1. English dominates the scene for communicating with potential authors, all journals using it for spreading the word about publication opportunities. In the digital age, the actual location of a journal diminished in importance, by comparison to print-only times, a fact that revolutionized the world of publishing, but also helped level the ground for English [3,28,31]. The typical recruitment pool of authors is the academic community supporting the journal. However, quality criteria require that only a portion of the publishing space be given to the in-house researchers and efforts need to be made to attract researchers from other institutions, preferably from abroad [35]. It naturally follows that a language understood by all should be available for informing authors. Five out of the total number of journals use the national language, Romanian, too, either as a first, or as a second choice. Three webpages maintain the francophone tradition of Romanian science and have a French variant too. A particular case is that of Hungarian: the journal displaying this language is rooted in a multicultural university, where Hungarian-led scholarship has a tradition of several centuries. With the help of various Hungarian donors, the journal appears (online and in print) with Hungarian dominating the publication space, offering also support for Hungarian language teaching in communication sciences (journalism). Occasionally, however, the journal publishes texts in English and Romanian (less frequent), a situation for which abstracts are required in English and Romanian. The parameter "publication languages" shows a diminishing interest for Romanian, with only three journals still using it for article presentation, and three journals requiring an abstract in Romanian either with the article, or as an additional language for abstracts. French language articles are hosted by seven journals, while German is used in four journals and, surprisingly for the Romanian scientific tradition, Spanish appears as a possible language of publication in two journals, in a systematic way. One journal lists only the above-mentioned major languages as possibilities but publishes also in Italian. The linguistic choices are not debated/argued for or against, as if the issue is invisible [15], with one notable exception: Ekphrasis, serving as a venue for research in film and cultural studies. The editors make a point of specifying that the articles published in the journal should use English and other European languages to maintain multiculturalism and interdisciplinarity, commenting that "we encourage authors to use English 
as contemporary lingua franca of research while considering multilingual expression a European trait. All articles must have exclusively English-language abstracts, key words, and affiliation of the author". At this point of research, with eight cities hosting all the 22 journals, a finer-grained analysis is required.

\subsection{Monolingual or Bi-/Multilingual? Scientific Journals and Linguistic Preferences by Historical Regions}

The national capital, Bucharest, with the numerous universities, research centers, major donors, and opportunities for employment of university graduates, is a special case, being branded as center versus the rest of Romanian cities. The linguistic traditions, in public life and in science, differ region by region. We tried to identify the pattern governing linguistic preferences by region, keeping in mind also the fact that while Hungarian and German are minority languages in Romania, German is also a language of upper culture for the whole country. Figure 1 below sums up the results.

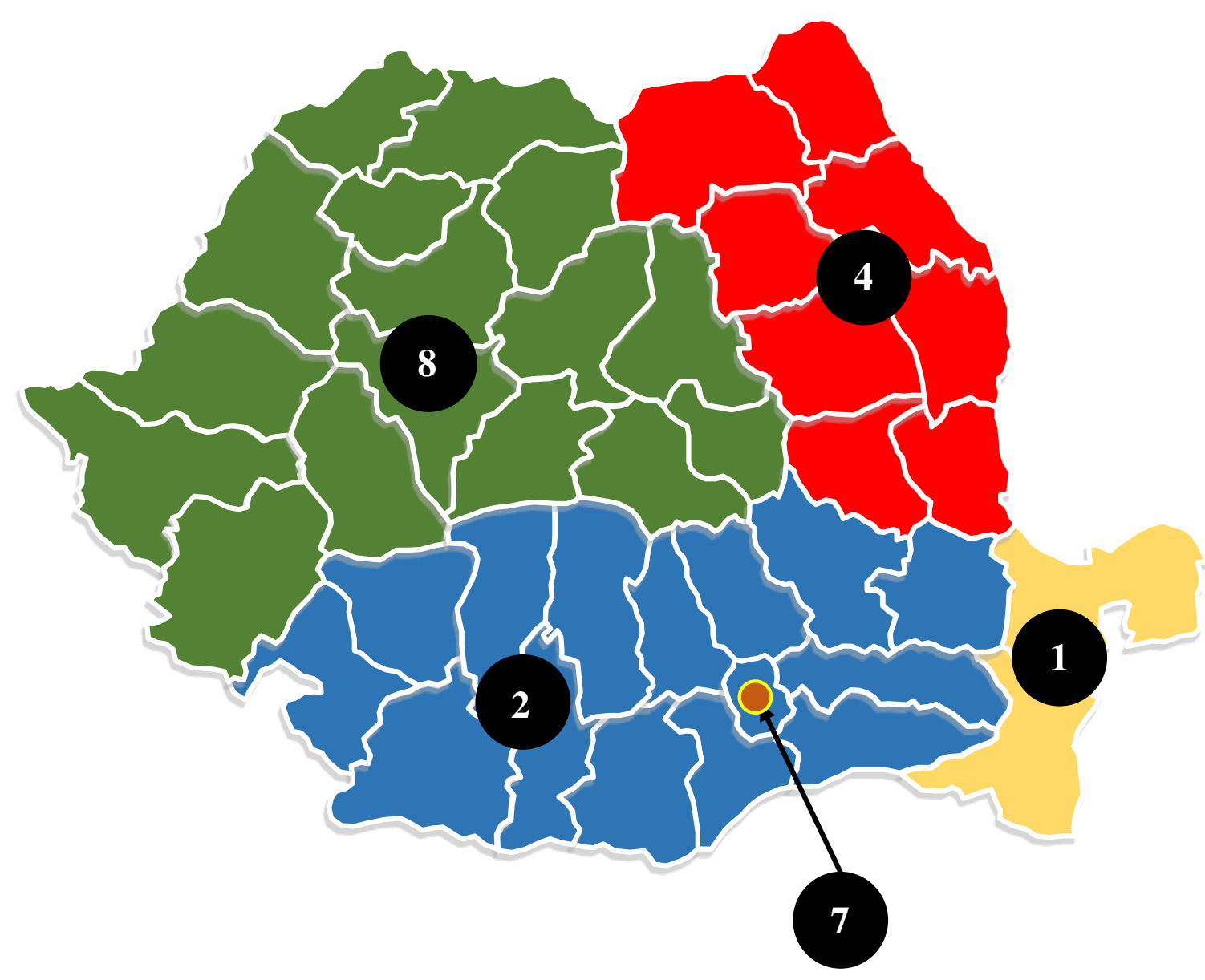

Legend:

\begin{tabular}{|l|}
\hline National capital \\
\hline Oltenia \\
\hline Transylvania-Banat \\
\hline Moldova \\
\hline Dobrogea \\
\hline
\end{tabular}

Figure 1. Number of journals by historical region.

The one journal in Dobrogea is a newcomer: established in December 2019, it rapidly gained indexations and still practices the "catch-all" policy, inviting submissions from the broad SSH area. The proportion of multilingual journals is highlighted by Figure 2 below. 


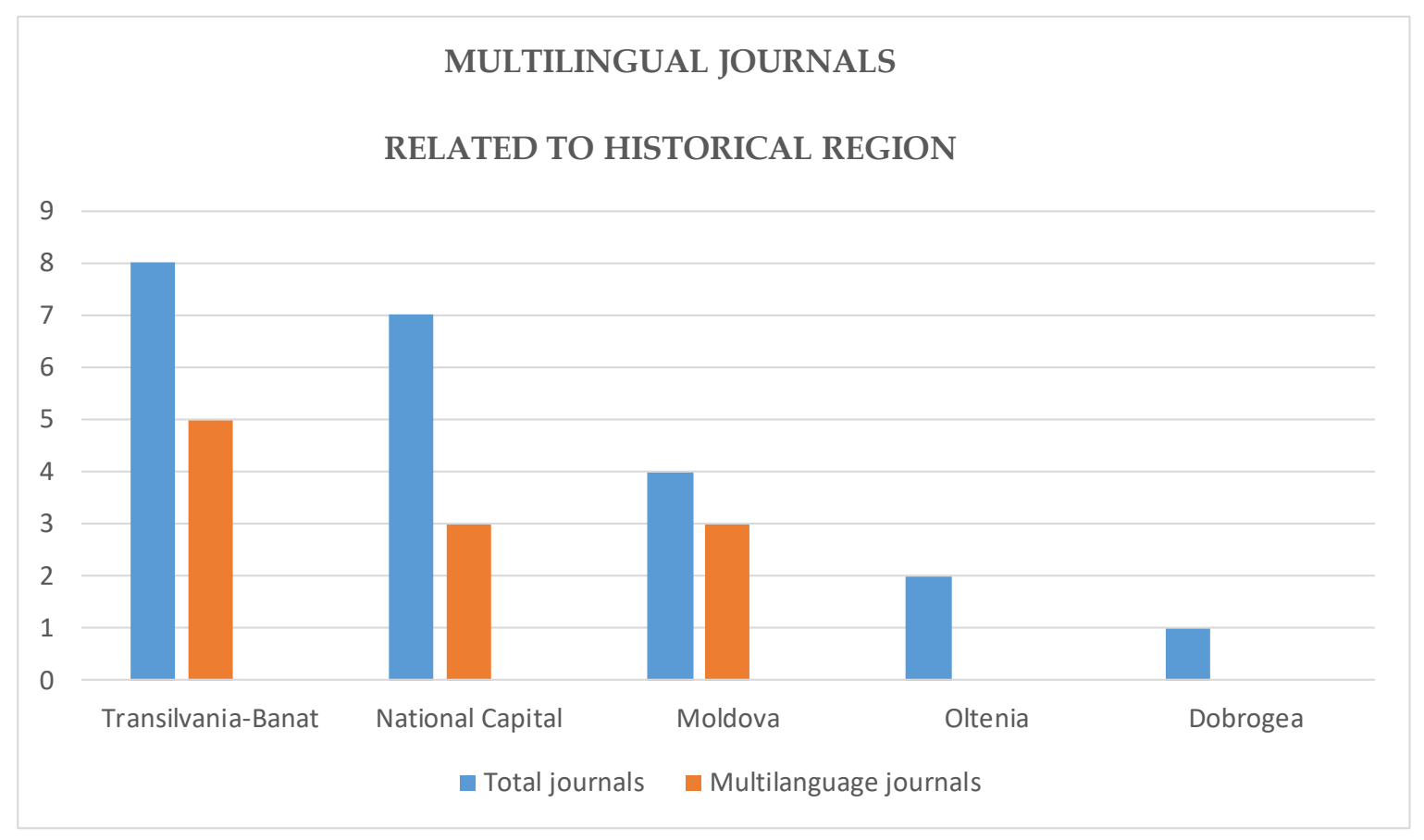

Figure 2. Linguistic preferences, by region.

Our initial hypothesis, that multicultural regions with academic traditions (TransylvaniaBanat) would favor multilingual journals with English plus other modern languages, is validated. While Dobrogea is also considered a multilingual region, it started a regular academic life in the form of a comprehensive university relatively recently, in 1990 (prior to that, a pedagogical institute functioned, established in 1961). The journal followed the mainstream trend of English as a lingua franca. None of the journals, however, propose linguistic services to potential authors. At best, submitting authors are advised to ask a colleague fluent in English or a native speaker to proofread the text of the article, a result which resonates with the remarks by Laura Muresan and Carmen Pérez-Llantada [31] on the role of English among social sciences scholars in Romania, writing in bi- or multiliterate environments. Their survey on Romanian academics' choice of languages for research communication points to the need for quality language services, such as language advisors and qualified translators, to aid researchers in their efforts to make scientific outputs available internationally [31], where native speakers of English are perceived as having an advantage over the non-native scholars $[16,31]$.

\subsection{Poles of Science}

Despite the promise to deal with communication science topics, 22 Romanian journals are too many given the size of the field of communication science in Romania. By eliminating the "catch-all" journals, only eight titles remain in focus (number 1, 2, 12, 13, 15, 16, 19, and 21 in Table 1), aiming at the advancement of communication sciences, grouped in two major cities: the national capital and Cluj-Napoca, the historical capital of the Transylvania region, as seen in Figure 3 below. 


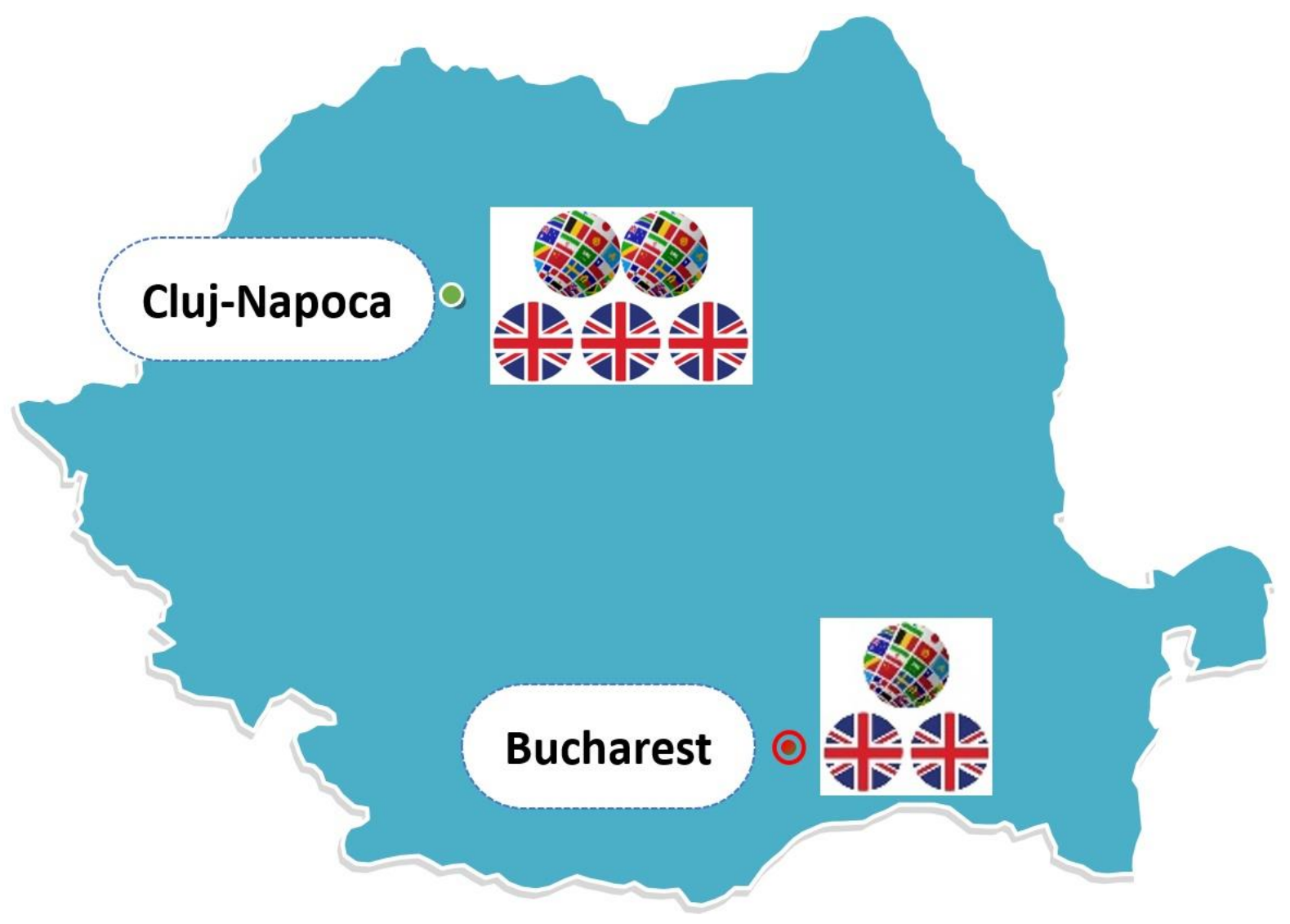

Legend:

Legend:
\begin{tabular}{|l|l|}
\hline & Multilingual journal \\
\hline & English journal \\
\hline
\end{tabular}

Figure 3. Bucharest vs. Cluj-Napoca, number of journals and language preferences.

In looking deeper for the motivation behind the number of journals focused on communication sciences, some features become salient: these two cities are the only ones with doctoral study schools in communication sciences [30] and the orientation towards enhancing the quality of the journals is obvious. Each city has one journal indexed in Web of Science (ESCI), Bucharest also having the only Scopus-indexed journal. The bar is raised higher: the recent evaluation process of journals in arts and humanities reinforced the criteria a journal needs to meet to improve its status in the national territory and to obtain the much sought-after impact factor [35]. Whether the language status will consecrate English as a lingua franca in SSH or a multilingual policy will continue and flourish depends not only on domestic factors. A more energetic intervention by the European Union towards fostering linguistic diversity in science may counterbalance the trend towards a monolingual (English) publication world. At this point, no such signs are visible [15] and the Transylvanian multilingualism, at least, is a result of the multilingual model of instruction. Otherwise, Romanians in an overwhelming number study English as their first additional language of choice, considering it most useful for personal use and career advancement [31], in academic life included, since the internationalization of Romanian higher education is accompanied by opening study lines in English at all levels of instruction [36]. 


\section{Conclusions and Further Directions of Research}

The findings presented in this study need further deepening, to investigate, for instance, the actual presence of languages other than English, French, and German in communication journals. The current tendency encountered in the journals is to strive towards higher quality, signaled by indexation in the top databases, a narrowing of the scientific area covered, and an interest in attracting foreign authors. However, until a clear image of the scientific landscape was available, deepening the analysis was not possible. Romanian journals strive to enhance their influence globally and overcome the periphery handicap, signaled by researchers interested in the larger image of the publishing world [16]. In doing so, they focus on the immediate requirements posed by the prestigious databases and by the national standards for recognition of scientific merit [27,35]. Romanian communication science journals follow the trend of participating in the scientific dialogue mainly by resorting to English to promote scientific output. The national language is not favored and the invisibility of the interest in multilingualism that researchers in the topic identified as specific for the European Union [15] extends over Romania too.

The findings also have practical and policy implications. Editors of scientific journals can encompass the domestic area in which they function and compare it with the international standards they strive for, authors can improve their decision-making process concerning the venue of their research output, and national bodies in charge of higher education and research can root their choices in these data. Also, editors can improve the presentation of the journals on their respective websites and add a better description of the journal's goals and scope, to make it more user-friendly. Hopefully, this research has also drawn attention to the communication sciences area as a domain in its own right, despite the ambiguity perpetuated by integrating this area with arts and humanities, as distinct from social sciences (alongside sociology, information sciences, and administrative studies) [13]. To conclude, the defining feature of the coming years will be the accelerating pace of incorporating quality criteria for improving the status of scientific journals, proven by impact factors calculated by WoS and Scopus, which will require an extra effort on the part of the publishers, while the choice of languages will depend on the macropolitical decisions at the European Union level, on funding and partnerships, and on the continuing optimism and selflessness of researchers championing multicultural exchanges of ideas.

Funding: This research received no external funding.

Institutional Review Board Statement: Not applicable.

Informed Consent Statement: Not applicable.

Data Availability Statement: Not applicable.

Conflicts of Interest: The author declares no conflict of interest.

\section{Appendix A}

Table A1. List of Romanian journals in communication science and their websites.

\begin{tabular}{|c|c|c|}
\hline 1. & Acta Universitatis Sapientiae, Communicatio & http://www.acta.sapientia.ro/acta-comm/communicatio-main.htm \\
\hline 2. & Acta Universitatis Sapientiae, Film and Media Studies & http://www.acta.sapientia.ro/acta-film/film-main.htm \\
\hline 3. & $\begin{array}{l}\text { Annals of the University of Craiova for Journalism, Communication } \\
\text { and Management }\end{array}$ & https://www.aucjc.ro/about/ \\
\hline 4. & Buletinul Institutului Politehnic din Iași secția Științe Socio-Umane & https://dppd.tuiasi.ro/cercetare/buletinul-ipi-sectia-socio-umane/ \\
\hline 5. & $\begin{array}{l}\text { Buletinul Științific al Universității Tehnice de Construcții București Seria: } \\
\text { Limbi Străine și Comunicare }\end{array}$ & http://lsc.rs.utcb.ro/index.html \\
\hline 6. & Communication Interculturelle et Littérature & https://revistacil.wordpress.com/ \\
\hline
\end{tabular}


Table A1. Cont.

\begin{tabular}{|c|c|c|}
\hline 7. & Cultural Intertexts & https://www.cultural-intertexts.com/ \\
\hline 8. & Ekphrasis. Images, Cinema, Theory, Media & https://www.ekphrasisjournal.ro/index.php?p=home \\
\hline 9. & HyperCultura & http://litere.hyperion.ro/hypercultura/ \\
\hline 10. & Information and Communication Sciences Research & http://icsr.unibuc.ro/ \\
\hline 11. & Journal of Communication and Behavioural Sciences & http://anale.spiruharet.ro/index.php/behav-sci/index \\
\hline 12. & Journal of Media Research & https://www.mrjournal.ro/ \\
\hline 13. & ME.DOK Média-Történet-Kommunikáció & https://www.medok.ro/en/medok/about-medok \\
\hline 14. & Professional Communication and Translation Studies & https://sc.upt.ro/ro/publicatii/pcts \\
\hline 15. & Revista Româna de Jurnalism si Comunicare & http://www.jurnalism-comunicare.eu/rrjc/index_en.php \\
\hline 16. & Romanian Journal of Communication and Public Relations & https://journalofcommunication.ro/index.php/journalofcommunication \\
\hline 17. & Saeculum ULBS & https://revistasaeculum1943.wordpress.com \\
\hline 18. & Social Sciences and Education Research Review & https://sserr.ro/ \\
\hline 19. & Studia Universitatis Babes-Bolyai-Ephemerides & http://studia.ubbcluj.ro/serii/ephemerides/ \\
\hline 20. & Studies in Visual Arts and Communication-An International Journal & https://journalonarts.org/ \\
\hline 21. & Styles of Communication & http://stylesofcomm.fjsc.unibuc.ro/home \\
\hline 22. & Technium Social Sciences Journal & https://www.techniumscience.org/index.php/socialsciences/about \\
\hline
\end{tabular}

\section{References}

1. Banks, D. Thoughts on Publishing the Research Article over the Centuries. Publications 2018, 6, 10. [CrossRef]

2. Swales, J.M. English as Tyrannosaurus rex. World Engl. 1997, 16, 373-382. [CrossRef]

3. Tardy, C. The role of English in scientific communication: Lingua franca or Tyrannosaurus rex? J. Engl. Acad. Purp. 2004, 3, 247-269. [CrossRef]

4. Kuteeva, M.; McGrath, L. Taming Tyrannosaurus rex: English use in the research and publication practices of humanities scholars in Sweden. Multilingua 2014, 33, 365-387. [CrossRef]

5. O'Neil, D. English as the lingua franca of international publishing. World Engl. 2018, 37, 146-165. [CrossRef]

6. Brosch, C. On the Conceptual History of the Term Lingua Franca. Apples J. Appl. Lang. Stud. 2015, 9, 71-85. [CrossRef]

7. Márquez, M.C.; Porras, A.M. Science Communication in Multiple Languages Is Critical to Its Effectiveness. Front. Commun. 2020, 5. [CrossRef]

8. Desrochers, N.; Larivière, V. Je Veux Bien, Mais Me Citerez-Vous? On Publication Language Strategies in An Anglicized Research Landscape. In Proceedings of the Communication Presented at the International Conference on Science and Technology Indicators, Valence, Spain, 14-16 September 2016.

9. Meneghini, R.; Packer, A.L. Is there science beyond English? Initiatives to increase the quality and visibility of non-English publications might help to break down language barriers in scientific communication. EMBO Rep. 2007, 8, 112-116. [CrossRef] [PubMed]

10. Salager-Meyer, F. Scientific publishing in developing countries: Challenges for the future. J. Engl. Acad. Purp. 2008, 7, 121-132. [CrossRef]

11. Alves, M.A.; Pozzebon, M. How to resist linguistic domination and promote knowledge diversity? Rev. Adm. Empresas 2013, 53, 629-633. [CrossRef]

12. Raitskaya, L.; Tikhonova, E. Multilingualism in Russian journals: A controversy of approaches. Eur. Sci. Ed. 2019, 45. [CrossRef]

13. Annex to Ministerial Order 6129/2016 on Minimum Necessary and Obligatory Standards for Conferring Didactic Titles in Higher Education, Professional Research and Development Degrees, the Quality of Doctoral Supervisor and the Habilitation Certificate. pp. 64-66. Available online: http://www.cnatdcu.ro/wp-content/uploads/2017/10/anexa-ordin-6.129_2016 -standarde-minimale_0.pdf (accessed on 21 July 2020).

14. European Commission Press Release. President Barroso Presents the Commissioner Designate for Romania. 30 October 2006. Available online: https:/ / ec.europa.eu/commission/presscorner/detail/en/IP_06_1499 (accessed on 16 September 2020).

15. Sivertsen, G. Balanced multilingualism in science. In BiD: Textos Universitaris de Biblioteconomia i Documentació; University of Barcelona: Barcelona, Spain, 2018; Volume 40. [CrossRef] 
16. Salager-Meyer, F. Writing and publishing in peripheral scholarly journals: How to enhance the global influence of multilingual scholars? J. Engl. Acad. Purp. 2014, 13, 78-82. [CrossRef]

17. Cernicova-Buca, M. The New Babylon: The World in the 21st Century. Scientific Bulletin of the "Politehnica" University of Timisoara. Trans. Mod. Lang. 2010, 9, 5-13.

18. Kulczycki, E.; Engels, T.C.E.; Pölönen, J.; Bruun, K.; Dušková, M.; Guns, R.; Nowotniak, R.; Petr, M.; Sivertsen, G.; Starčič, A.I.; et al. Publication patterns in the social sciences and humanities: Evidence from eight European countries. Scientometrics 2018, 116, 463-486. [CrossRef]

19. Soler, J. Academic Publishing in English: Exploring Linguistic Privilege and Scholars' Trajectories. J. Lang. Identit. Educ. 2019, 18, 389-399. [CrossRef]

20. Den Hertog, P.; Jager, C.-J.; Vankan, A.; Te Velde, R.; Veldkamp, J.; Aksnes, D.; Sivertsen, G.; Van Leeuwen, T.; Van Wijk, E. Science, Technology \& Innovation Indicators. Thematic Paper 2: Scholarly Publication Patterns in the Social Sciences and Humanities and Their Relationship with Research Assessment. 2014. Available online: http://dialogic.nl/documents/other/sti2_themepaper2 .pdf (accessed on 9 January 2021).

21. Central and Eastern Online Library (CEEOL). Available online: https:/ / www.ceeol.com/ (accessed on 3 October 2020).

22. Index Copernicus. Available online: https:/ /journals.indexcopernicus.com/ (accessed on 27 September 2020).

23. Martín-Martín, A.; Orduna-Malea, E.; Thelwall, M.; López-Cózar, E.D. Google Scholar, Web of Science, and Scopus: A systematic comparison of citations in 252 subject categories. J. Inf. 2018, 12, 1160-1177. [CrossRef]

24. Berger, C.R.; Roloff, M.E.; Roskos-Ewoldsen, D.R. What is Communication Science? In The Handbook of Communication Science; SAGE Publications Inc.: Washington, DC, USA, 2010. [CrossRef]

25. Palea, A. Identitatea Profesionala a Specialistilor în Relatiii Publice [Professional Identity of Public Relations Specialists]; Tritonic: Bucharest, Romania, 2013.

26. Coravu, R.; Constantinescu, M. A Study in Gold: Top Romanian Scholarly Journals and Their Open Access Policies. Rom. J. Libr. Inf. Sci. 2018, 14, 104-112. [CrossRef]

27. Situatia Curenta a Revistelor Recunoscute CNCSIS [The Current Status of Journals Recognized by the National University Research Council]. 2011. Available online: https://uefiscdi.gov.ro/articole/1991/Situatia-curenta-a-revistelor-recunoscuteCNCSIS-2011.html (accessed on 22 October 2020).

28. Sīle, L.; Guns, R.; Sivertsen, G.; Engels, T. European Databases and Repositories for Social Sciences and Humanities Research Output: Report (July). 2017. Available online: https:/ / doi.org/10.6084/m9.figshare.5172322 (accessed on 22 October 2020).

29. Florian, R.; Florian, N. Majoritatea Revistelor Ştiinţifice Româneşti nu Servesc Ştiinţa [The majority of Romanian Scientific Journals do not Serve Science]. Ad. Astra. 2006, 5, 1-26. Available online: http://www.ad-astra.ro/journal/9/florian_reviste_locale.pdf (accessed on 26 September 2020).

30. Gelan, V.E. Dezmățul în Limbi Străine al Revistelor Academice Românești de Filosofie [The Deception in Foreign Languages of Romanian Academic Journals of Philosophy]. 16 July 2014. Available online: https:/ /www.contributors.ro/dezma\%c8\%9bul-inlimbi-straine-al-revistelor-academice-romane\%c8\%99ti-de-filosofie/ (accessed on 5 July 2020).

31. Muresan, L.-M.; Pérez-Llantada, C. English for research publication and dissemination in bi-/multiliterate environments: The case of Romanian academics. J. Engl. Acad. Purp. 2014, 13, 53-64. [CrossRef]

32. Asociatia Romana de Relatii Publice [Romanian Association of Public Relations]. Educatie [Study Programs in Communication Sciences]. Available online: http:/ / arrp.eu/educatie/ (accessed on 17 October 2020).

33. Ware, M.; Mabe, M. The STM Report: An Overview of Scientific and Scholarly Journals Publishing; International Association of Scientific, Technical and Medical Publishers: Oxford, UK, 2009; Available online: www.stm-assoc.org/2009_10_13_MWC_STM_Report.pdf (accessed on 29 August 2020).

34. Law 1/2011. Available online: https://lege5.ro/Gratuit/geztsobvgi/statutul-personalului-didactic-lege-1-2011?dp=gq2 tomryge2da (accessed on 5 September 2020).

35. Metodologia de Evaluare și Clasificare a Editurilor, Colecțiilor și Revistelor Științifice, în Vederea Recunoașterii și Clasificării din Partea Consiliului Național al Cercetării Științifice a Revistelor Științifice și Editurilor din Domeniul Fundamental al Științelor Umaniste (Aprobată Prin OM 5550/11.09.2020) [Methodology of Evaluating and Classifying Publishing Houses, Collections and Scientific Journals by the National Research University Council for the Major Domain of Humanities, Approved by Ministerial Order 5550/11.09.2020]. Available online: http://www.cncs-nrc.ro/wp-content/uploads/2020/09/Anexa_OMEC_5550_11_09_2 020.pdf (accessed on 7 November 2020).

36. Deca, L.; Egron-Polak, E.; Fiț, C.R. Internationalisation of Higher Education in Romanian National and Institutional Contexts. In Higher Education Reforms in Romania; Curaj, A., Deca, L., Egron-Polak, E., Salmi, J., Eds.; Springer: Cham, Swittzerland, 2015; pp. 127-147. 